\title{
The Narration of Cultural Landscape as a Mean for Reactivating Marginal Areas
}

\author{
Marco Vedoà
}

Abstract

The paper deepens the role and the opportunity offered by ICTs and web GIS systems in the narration and representation of the cultural landscape, focusing especially on fragile areas. European marginal landscapes excluded from the global economic and social processes that have also suffered, and in many cases are still suffering, political and planning actions that have interrupted the historical connections between local people and their territory [Tarpino 2016; Del Molino 2016]. According to the European and Italian framework on cultural landscape (European Landscape Convention 2000, Codice dei Beni Culturali e del Paesaggio 2004) and on marginal areas (Strategia Nazionale per le Aree Interne), cultural heritage is considered one of the potential engine for the reactivation of the territories, hence its narration plays a relevant role in this process. The paper also presents several cases and typologies of narration and digitization of the cultural landscape and the different impacts they have on the reactivation of local communities: the 'formal' approach developed by local administrations mainly with cultural heritage GIS systems; and the 'informal' approach developed by spontaneous local communities and external networks with different ICTs tools and social networks. Finally, further directions for the representation and narration of the cultural landscape are suggested in order to drive the reactivation of fragile areas.

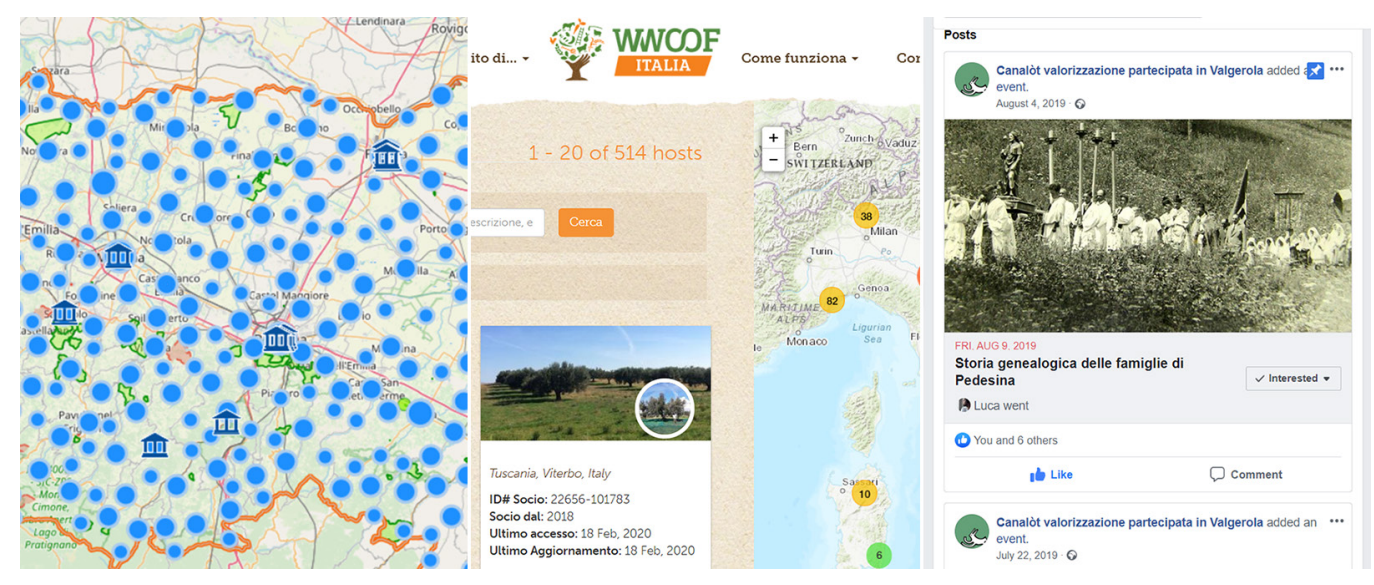




\section{Fragile Cultural Landscape, a complex definition, and a complex representation}

Antonella Tarpino indicates that the fragile landscape "The fragile landscape originates where the shapes of the landscape have modulated on the surgical lines of limits, borders, and margins. These are the most proper words with which it was understood, in the era of the State-Nation cartography, to mark the space, it was mentioned, of real negative quality" [Tarpino 2016, p. 12]. The author refers to landscapes that have suffered - and in many cases are still suffering - political and planning actions that have interrupted the historical connections between local people and their territory. Moreover, the focus on the definition "margin" indicates landscapes that have in many cases been excluded from the global economic and social processes. According to this definition, the fragile landscape can be identified not only in remote rural areas nestled in the mountains and far from relevant centers, but also in urban and suburban contexts in which limits, borders, and margins are sometimes invisible, and not everywhere surgical. Examples of these invisible delimitations could be represented by the social and demographic conditions, residential segregation and its features. Considering also the debate on marginality in a European view, many countries are experiencing the same issues [Del Molino 20 16; Latocha et al. 20 19] but at the moment a European definition of 'fragile landscape' is not possible to find in literature. At the national level, the first definition of marginality has been provided by 'Strategia Nazionale per le Aree Interne' (DPS 20 I4). The document defines the marginality degree of each Italian municipality depending on the accessibility to basic public services, the time citizens must travel to reach the nearer hospital, high-school, and Silver category railway station. The policy considers, at least for the identification process, the physical marginality and social, economic and demographic features are supposed. At the same time, 'Strategia Nazionale per le Aree Interne' recognizes the latent potential of the cultural landscape of local communities, cultural tangible and intangible heritage, and the natural environment. These are recognized as the possible engines to reactivate marginal areas with experiential and sustainable tourism practices. The document is according to the most updated debate on Cultural Landscape, the tight relation between heritage, inhabitants, tangible and intangible culture, and place which is stated both in national and international regulatory frameworks. Some examples are The Italian regulatory framework 'Codice dei Beni Culturali e del Paesaggio'; at European level by European Landscape Convention guidelines (Council of Europe 2000); at the global scale on the Unesco approach to cultural landscapes (Unesco 20 I3). Moreover, this relation has been deepening in literature thanks to the contribution of Alberto Magnaghi who defined the concept of 'Patrimonio Territoriale' [Magnaghi 20I0], and Salvatore Settis who showed first the relation between cultural heritage and place, and then the "common good" nature of landscape [Settis 20I0]. In this perspective, the multifaceted relations of

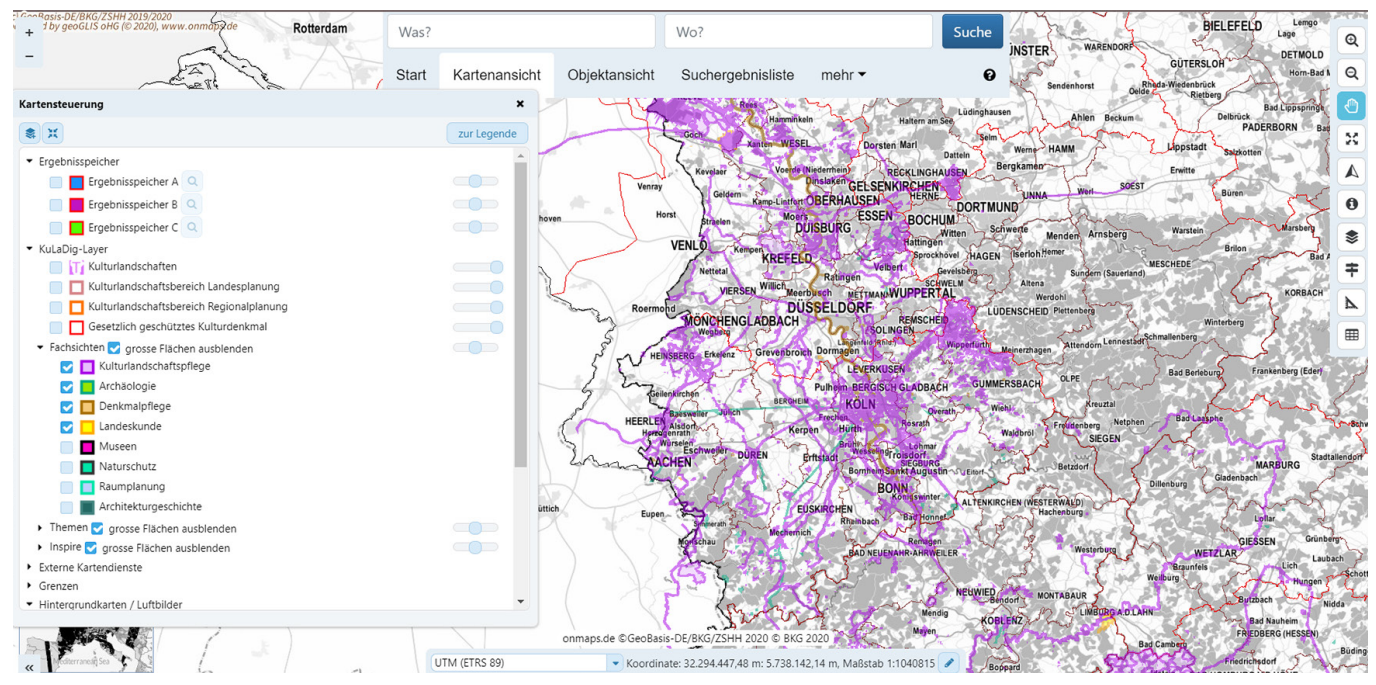


the landscape can be summed in the idea of 'cultural landscape' which combines heritage, nature, and changes made to nature by human activities. For these reasons, the narration and representation of the cultural landscape [Salerno 2008] is a relevant practice for the reactivation of the most marginal areas, on one hand, to preserve the cultural heritage especially the intangible aspects - and on the other side to communicate values to push reactivation processes, i.e. sustainable and experiential tourism, agricultural specialties farms, and social activities.

The narration of the cultural landscape with ICTs and digitization. The 'formal' approach. Local administrations, cultural heritage GIS and citizens

The narration of the cultural landscape has been experimented during the last years with different ICTs tools, especially with web Cultural Heritage GIS systems which are open interactive maps and catalog that are able to communicate and teach the history and the tangible and intangible cultural heritage of a certain area. The idea behind these tools was the necessity of local administrations, from the regional to the municipal level, to gather information and preserve the memory of the local cultural landscape. For this reason and thanks to the accessibility of ICTs, local administrations across Europe have been developing during the last two decades many examples of $\mathrm{CH}-\mathrm{GlS}$ that in many cases have also
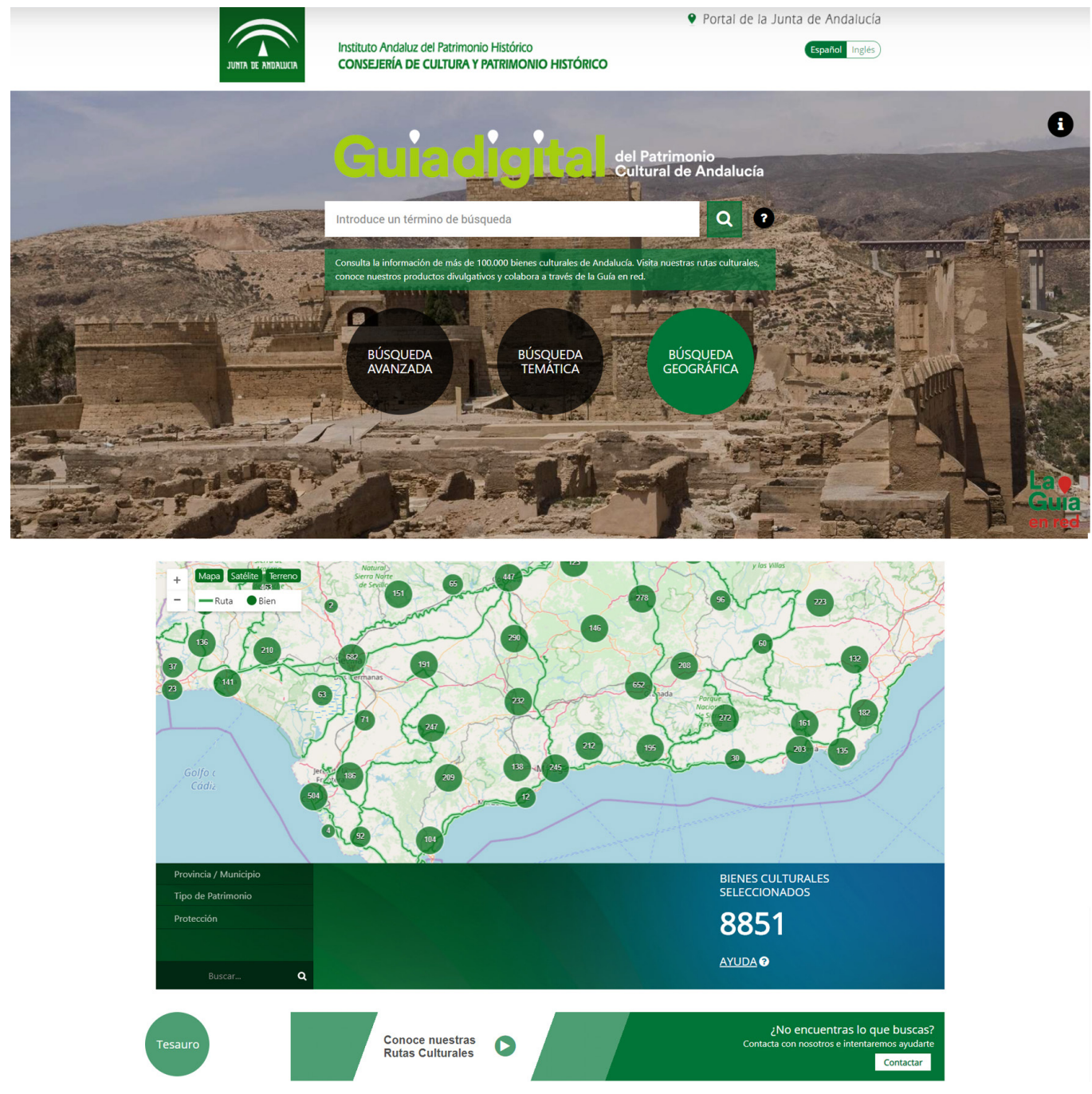
involved local citizens in the development process. The reason behind the development of these tools is the will of cataloging the tangible and intangible cultural heritage to know the real entity of the cultural heritage and to prevent the loss of the local identity in the most marginal areas. An example of these online tools is Kultural Landschaft Digital (KuLaDig) project promoted by the local governments of NordRhein-Westfalen, Hessen and Rheinland-Pfalz in Germany [Burggraaff 20 I7]. The web platform is [https:/www.kuladig.de] suggests an ongoing-mapping process of the cultural landscape to collect the and understand the evolution of the cultural landscape of the region. The online tool [https://www.kuladig. de/karte] collects and represents a long list of maps and data regarding, on one hand the natural heritage, and tangible and intangible cultural heritage, and on the other geophysical data, plans and even historical maps. KuLaDig project offers the opportunity to visualize all these layers on a dedicated webGIS application embedded on the website, and compare data by overlapping different layers. The tool also allows users to interact with the maps to explore the different cultural landscapes and to consult the database composed by detailed charts of each landmarks, traditions and natural heritage areas (fig. I).

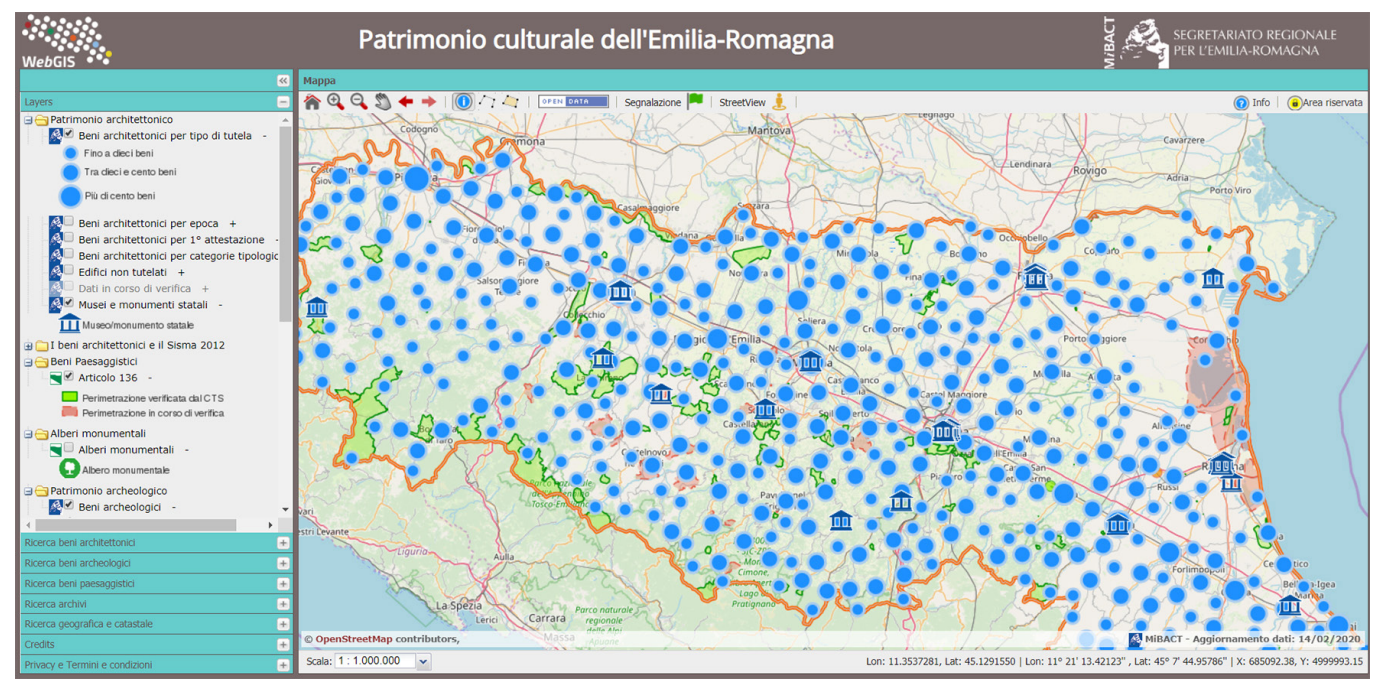

Another example of this approach is 'Guia Digital del Patrionio Cultural de Andalucia' (Digital Guide of the Andalusian Cultural Heritage) [https://guiadigital.iaph.es/] promoted by the regional government of Andalusia in Spain. The tool is a comprehensive atlas of the tangible and intangible cultural heritage of the region and it focuses especially on local traditions. The web site (fig. 2) offers the opportunity to explore on the web map the relevant landmarks, handcrafts, and traditions of the region, and it also offers several thematic routes and informative chart for tourists [Cacho, Díaz 20 I7].

In Italy, an example of these online tools is the Cultural Heritage GIS of Emilia-Romagna Region [https://www.patrimonioculturale-er.it/webgis/] promoted by the local administration and the Ministry of Culture. Similarly to KuLaDig project, the web tool maps the cultural heritage of the region (fig. 3), but it limits the cataloguing process only on the tangible and historical elements. The project also maps the museum collections and the historical archive of the region. Moreover, the platform allows the interaction with external users who can suggests to the administration elements or places that are not yet included in the regional database. The analysis of these three cases allows defining a first reflection on the ability of the cultural heritage GIS to visualize, and especially narrate the cultural landscape. Open webmaps offer a comprehensive knowledge of the cultural heritage that can be consulted for free, but they seem to lack in two crucial aspects. First, they lack a proper communication on the 


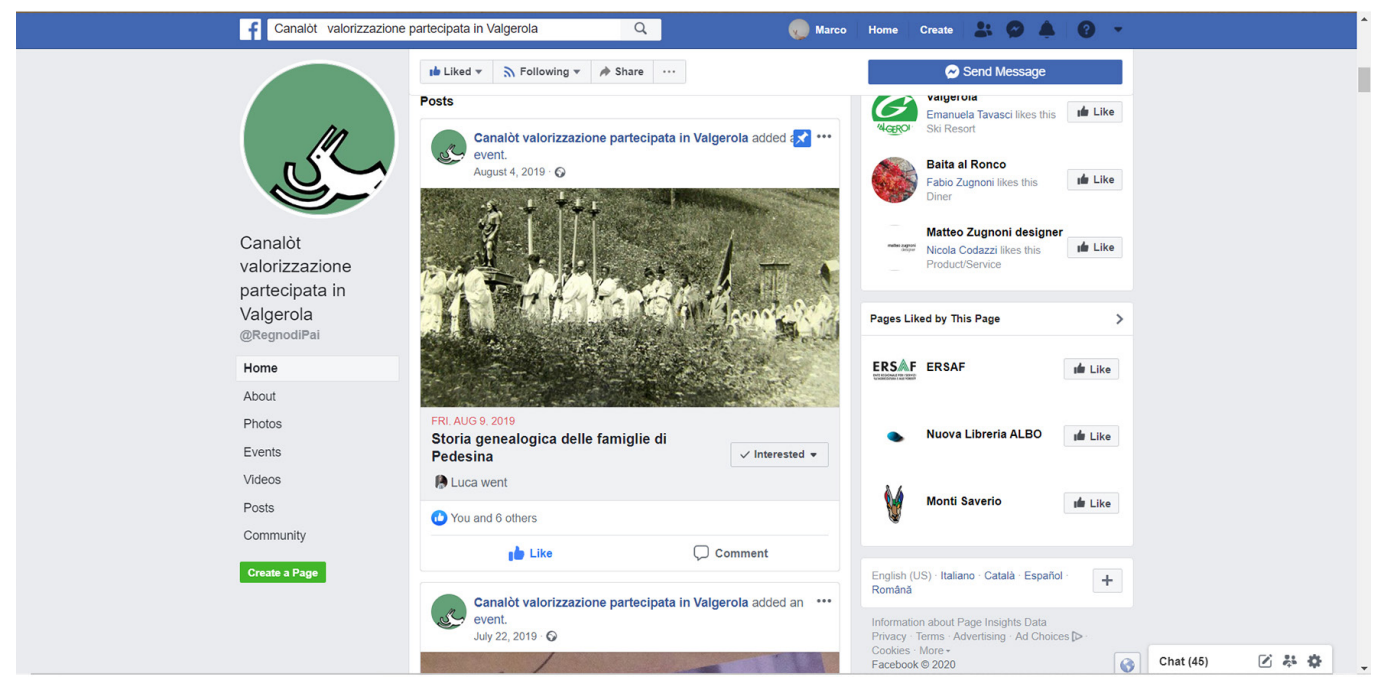

internet and this issue limits the connection between the tool and the potential local and global users. The promotion of these web platforms is not performed properly and only the professionals and the engaged audience use these tools. Second crucial issue concerns the usability. The user experience and interaction of the three proposed webmaps and also the navigation of their catalogs can be performed by user with at least intermediate skills in the use of webmaps. This limit could interfere with the openness initial intent to give to everyone a free online tool to discover the cultural landscape of a territory. These two issues could even play against the valorization of the cultural landscape because they are not able to involve and to reach the potential users. Moreover, the direct involvement of locals in the development phase could be difficult. Older citizens, schools, and the local associations - who are the ones that can mostly contribute to the record of the memory of a place - need the supervision and the actions of specialists, not only in cultural heritage but also trained technician in the storytelling techniques and the webGIS development. For this last reason, the regional cultural landscape webmaps difficultly involve users in the mapping or the managing processes - although they provide the tools - in the better cases the action of the users is limited in reporting new elements to catalog. From these considerations, the development of a cultural heritage webGIS represents a relevant process for the cataloging of the cultural landscape, for the preservation of the memory and the value of the tangible

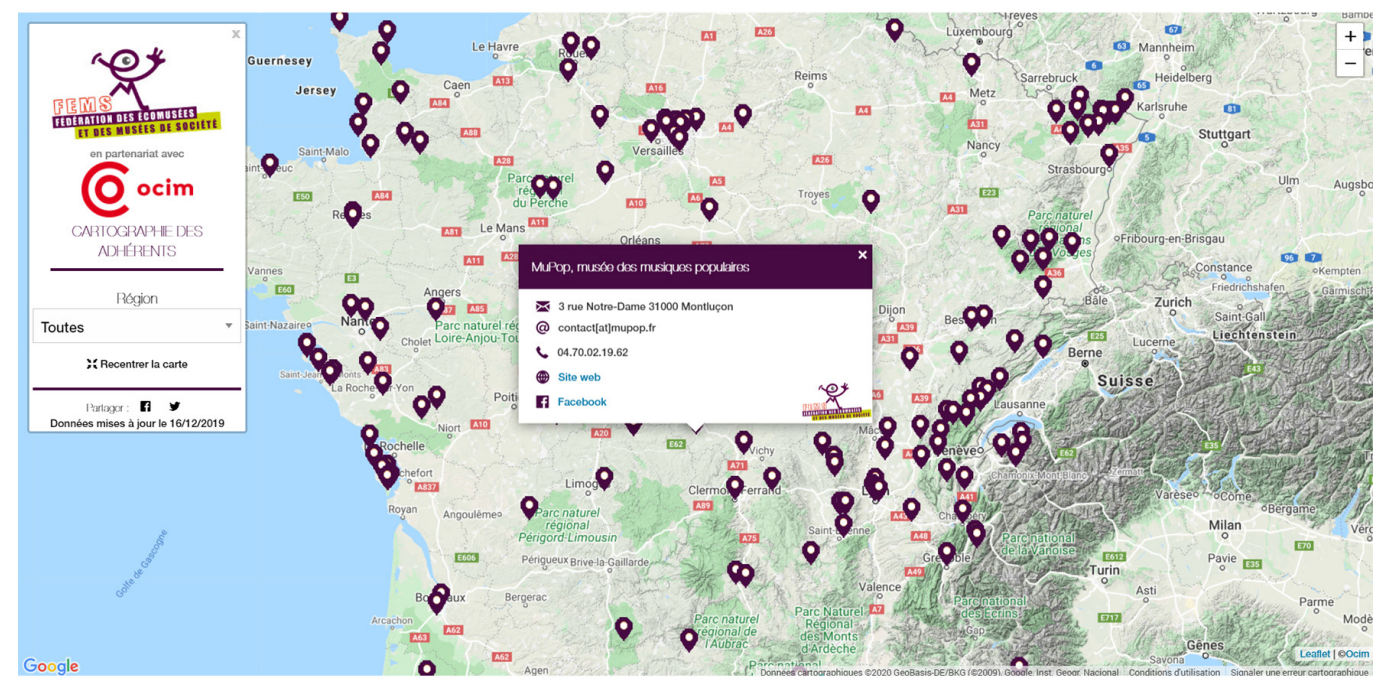


and intangible cultural heritage, but this approach seems limited to specialist and engaged citizens; it difficultly could contribute in the reactivation of the territories, especially the most fragile and marginal ones.

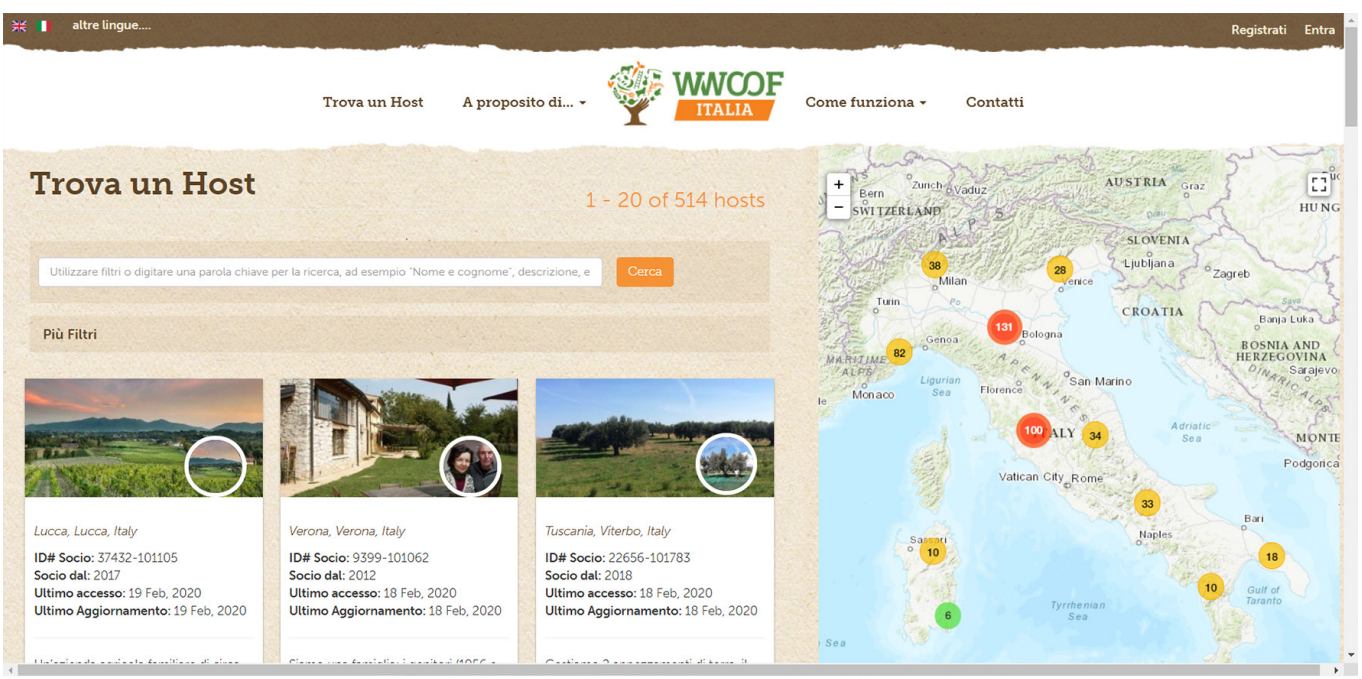

\section{The informal approach. Bottom-up initiatives and Global Networks}

Nearly after the development of the first 'official' cultural heritage GIS, also local associations spontaneously started to represent their cultural landscape with different ICTs to defend specific values considered essential parts of the local community. Communities for the preservation of peculiar agricultural products, for defending the natural and cultural heritage, or associations for the dissemination of handcrafts that risks disappearing are increasing across Europe. Thanks to the appearance of free online applications, whether they are free open source software (i.e. OpenStreetMap, Umaps, and Storymap), or not (i.e. Google My Maps, Google Tour Creator, and Izi.travel), citizens are developing complex storytelling that offers an innovative point of view for the cultural landscape narration. These practices can be found mostly on the social networks which are used as a means to build a stronger local identity by disseminating the value of their cultural landscape, and by organizing information events and activities. Three comprehensive example of these innovative narrations could be: Canalòt, Valorizzazione partecipata in Valgerola [https://www.facebook.com/RegnodiPai/] that aims at the participatory valorization of the historical local cultural landscape of a lateral valley of Valtellina with social networks and aggregation activities (fig. 4); Portobeseno, viaggio tra fonti storiche e sorgenti web [http://www.portobeseno.it/] which is an association to promote the cultural tangible and intangible heritage of the Alto Garda area with the direct involvement of schools and local citizens in digital and on-field activities; and Cerchio d'Acqua [Vedoà 2019] which is promoting the participatory valorization of the historical water network of Sabbioneta by implementing an interactive open geoblog. These practices can at glance seem isolated but they are part of a trend that is building a constellation of practices for the reactivation of marginal areas. The use of social networks and the will of disseminating their activities could drive the constitution of national and international networks to be relevant in the public and political debate. The cases of Ecomuseums networks, its evolution and the narration they provide of the cultural landscape, can offer a possible scenario for the future of bottom-up practices. Ecomuseums are bottom-up initiatives gathered in national and international networks, that have been further institutionalized with regional regulations in the last years. These initiatives aim at the organization of actions and events on the territory with the use of ICTs to promote the cultural landscape - its tangible and intangible 
peculiarities - to local citizens and potential tourists [Dal Santo 20 I7]. Ecomuseums network is a constellation of similar practices (fig. 5) that is now operating in several European and South American countries.

Considering external actors that can act in the narration of the cultural landscape and its reactivation, SlowFood and Wwoof networks are the most relevant examples. SlowFood is an international no-profit organization that aims to valorize typical agricultural products and the producers' communities and place. The organization offers support and visibility to the communities of producers, mainly in marginal areas, by giving the official brand, the SlowFood Presidium [https://mww.slowfood.it]. WWOOF Network (World-Wide Opportunity in Organic Farms) is also a no-profit organization that connects farmers and local agricultural communities with experiential tourists, people who look for authentic local experiences in farms and social communities in marginal areas (fig. 6). These two cases show that there is an innovative approach for the narration of the cultural landscape in which ICTs are used as a means to represent the connection of local communities to the global audience.

\section{Conclusions}

An active narration and communication of the marginal cultural landscapes should be focused on connections rather than on the singular tangible and intangible elements. Cultural heritage GIS and webmaps offer useful database to know and preserve the memory of the cultural landscape, the history, the natural heritage and the traditions of a place, but in marginal areas, they lack a proper communication. Due to the high technical level and the lack of a proper promotion, the approach of the cultural heritage webmaps and GIS difficultly involves citizens in the management and valorization of their cultural landscape and this issue seems to not allow a proper reactivation process according to the academic literature [Settis 20 I0; Magnaghi 20 I0] and to the international frameworks (Council of Europe 2000, Unesco 2013). This aspect could be overcome if local administrations start to involve local citizens and their practices directly. Finally, a representation of these practices is desirable because the development of maps - or even atlas - that can show data and activities of local communities and their global connections could offer an innovative point of view for the visualization of the marginality (fig. 7). This representation could show constellations, patterns, and lines of practices [Bonfantini 20 I7] that can first build stronger global communities, and then be a relevant tool for experts. It could be an innovative tool for the valorization of the most marginal cultural landscapes, on one hand by regenerating the constructive link between tourism and cultural heritage, and on the other by giving an open database for decision-making processes and for the planning of territorial policies.

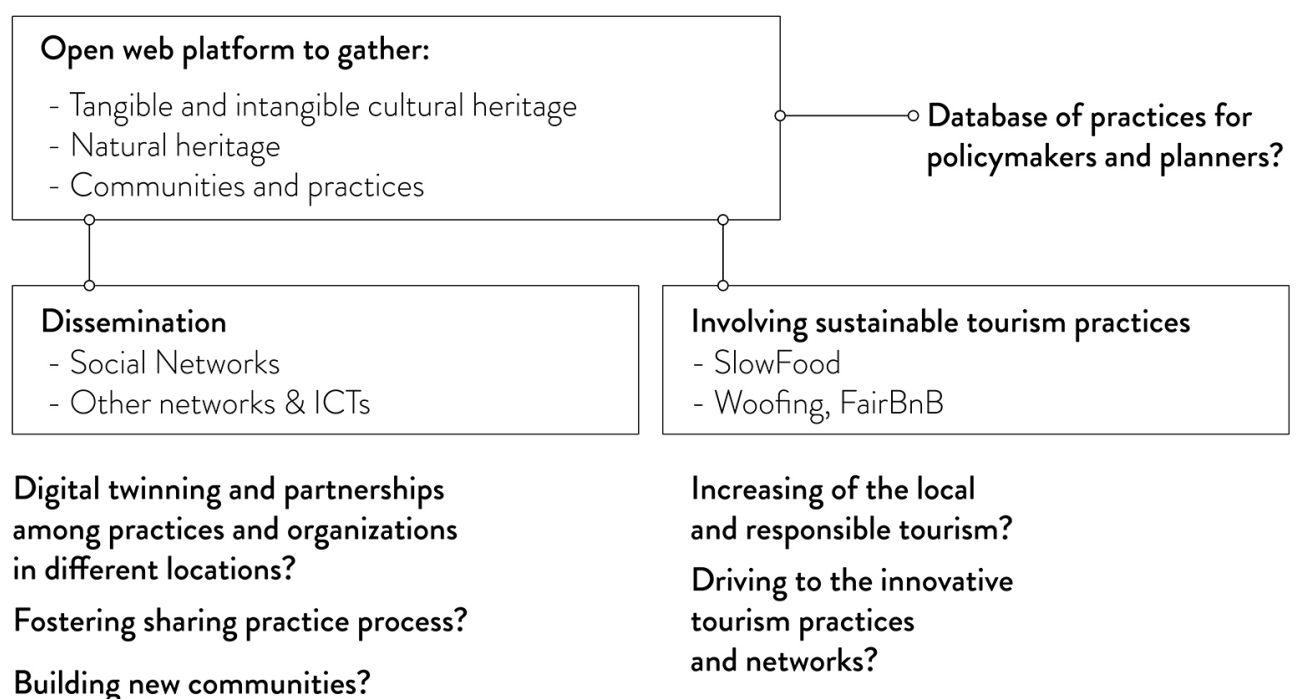




\section{References}

Agnieszka Latocha, Kamila Reczyńska, Tomasz Gradowski et al. (2019). Landscape memory in abandoned areas - physical and ecological perspectives (Central European mountains case study). In Landscape Research, 44(5), 600-6I3.

Bonfantini Bertrando (2017). Dati informativi aperti per l'attivazione dei contesti locali. In Daniele Villa (Coord.). Open Data for Cultural Heritage. Place Based Digital Humanities between Representation, Design and Innovation, pp. I5-20. Milano: Planum Publisher.

Burggraaff Peter et al. (2017). KuLaDig - a cooperation platform for recording and preserving the cultural landscape and its development. In Publications of the German Society for Photogrammetry, p. 203.

Dal Santo Raul, Baldi Nerina, Del Duca Andrea, Rossi Andrea (2017). The Strategic Manifesto of Italian Ecomuseums. In Museum International, 69( I-2), pp. 86-95.

Del Molino Sergio (2016). La España vacía:Viaje por un país que nunca fue. Madrid:Turner.

DPS, Dipartimento per lo Sviluppo e la Coesione territoriale (2013). Strategia nazionale per le aree interne: definizione, obiettivi, strumenti e governance. documento tecnico collegato alla bozza di Accordi di partenariato trasmessa alla CE il 9 dicembre 2013. Ministero dell'Economia e delle Finanze.

European Commission (20ll). Open data. An engine for innovation, growth and transparent governance. Luxembourg: EC Publications Office.

European Commission (2018). Innovation in Cultural Heritage - For an integrated European Research Policy. Luxembourg: EC Publications Office.

Fernandez Cacho Silvia, Carrera Díaz Gema, Ortiz Lozano Lorena (2017). Open Information on Andalusian Cultural Heritage. In Daniele Villa (Coord.). Open Data for Cultural Heritage. Place Based Digital Humanities between Representation, Design and Innovation, pp 3I-40. Milano: Planum Publisher

Magnaghi Alberto (20 I0). Il progetto locale. Verso la conoscenza di luogo. Torino: Bollati Boringhieri.

Salerno Rossella, Casonato Camilla (2008). Paesaggi Culturali/Cultural Landscapes. Rappresentazioni Esperienze Prospettive. Roma: Gangemi.

Settis Salvatore (20I0). Paesaggio Costituzione Cemento. Torino: Einaudi.

Tarpino Antonella (2016). Paesaggi fragili.Torino: Einaudi.

Vedoà Marco (2019). The art of drawing, interactivity and territorial branding: The territory narration in cultural heritage education. In P. Belardi (ed.). Reflections the art of drawing the drawing of art. $41^{\circ}$ Convegno Internazionale dei Docenti delle Discipline della Rappresentazione, Perugia 19-21 sept 2019, pp. I791-1796. Roma: Gangemi Editore.

Vinci Ignazio (20 I0). Pianificazione strategica in contesti fragili. Firenze: Alinea Editrice.

\section{Author}

Marco Vedoà, Politecnico di Milano, marco.vedoa@polimi.it

To cite this chapter. Vedoà Marco (2020). The narration of cultural landscape as a mean for reactivating marginal areas. In Arena A., Arena M. Brandolino R.G., Colistra D., Ginex G., Mediati D., Nucifora S., Raffa P. (a cura di). Connettere. Un disegno per annodare e tessere. Atti del $42^{\circ}$ Convegno Internazionale dei Docenti delle Discipline della Rappresentazione/Connecting. Drawing for weaving relationships. Proceedings of the 42th International Conference of Representation Disciplines Teachers. Milano: FrancoAngeli, pp. 3827-3834. 